\title{
Freshwater, Terrestrial, and Marine Turtles of Florida ${ }^{1}$
}

\author{
Patricia Sprott, Frank J. Mazzotti, and Jocie A. Graham²
}

\section{Introduction}

Florida is home to 25 species of turtles representing seven families. Turtles (including tortoises and terrapins) can be terrestrial, aquatic, or semi-aquatic. In aquatic food pyramids, some turtles are top carnivores since they feed on other small aquatic animals and rarely become food themselves. Like other reptiles, turtles are poikilothermic (dependent on their surroundings for their body temperature).

Adapted to both tropical and temperate climates, turtles can be found on every continent except Antarctica. The major single factor responsible for the turtle's continued success is its protective armor. The body of a turtle is encased in a shell composed of two parts (Figure 1). The upper shell is called the carapace and is covered with plates called scutes, or in the case of softshell and leatherback turtles, a leathery skin. The lower shell, or plastron, is usually joined to the carapace by a bony bridge. Most turtles can draw their head and legs partly or completely inside their shells for protection.
All turtles lack teeth. Instead, the jaws are covered by a horny material that forms a beak much like that of a bird. The beak may be serrated or smooth but always has a sharp cutting edge for shearing off flesh or vegetation. Depending upon the species, turtles can be herbivorous, carnivorous, or omnivorous. Many turtles spend much of their lives in and around the water, but all turtles lay their eggs on land, including sea turtles, which nest every summer on many of Florida's beaches. Female turtles use their hind feet to dig a hole in dirt or sand, then deposit their eggs and cover them; they then leave their nests, never to return. Eggs are incubated by the heat of the sun and the insulation of the sand or dirt. Many types of mammals, birds, fishes, crustaceans, other reptiles, and even humans dig into the nests and eat the eggs, or feed upon the hatchlings. The odds of a hatchling reaching maturity are slim; among sea turtles it is estimated that three in every 1,800 eggs laid become adults. Although they are among some of the most successful animals, some species of turtles have become extinct in the last 200 years. No amount of armor can protect them from habitat encroachment, nest destruction, and killing for meat and decorative shells. The best

1. This document is WEC-173, one of a series of the Department of Wildlife Ecology and Conservation, University of Florida, Florida Cooperative Extension Service, Institute of Food and Agricultural Sciences. Published:1993, as SS-WIS-57. Revised: November, 2003. Please visit the EDIS Web site at http://edis.ifas.ufl.edu.

2. Originally written by: Patricia Sprott, former Wildlife Information Specialist; revised by: Jocie A. Graham, Biological Scientist and Frank J. Mazzotti, Associate Professor, Wildlife Ecology and Conservation Department, University of Florida, Ft. Lauderdale Research and Education Center, FL 33314; Florida Cooperative Extension Service, Institute of Food and Agricultural Sciences, University of Florida, Gainesville, 32611.

The Institute of Food and Agricultural Sciences (IFAS) is an Equal Employment Opportunity - Affirmative Action Employer authorized to provide research, educational information and other services only to individuals and institutions that function without regard to race, creed, color, religion, age, disability, sex, sexual orientation, marital status, national origin, political opinions or affiliations. For information on obtaining other extension publications, contact your county Cooperative Extension Service office. Florida Cooperative Extension Service / Institute of Food and Agricultural Sciences / University of Florida / Larry R. Arrington, Interim Dean 
defense for these creatures is a better human understanding of their importance in natural ecosystems.

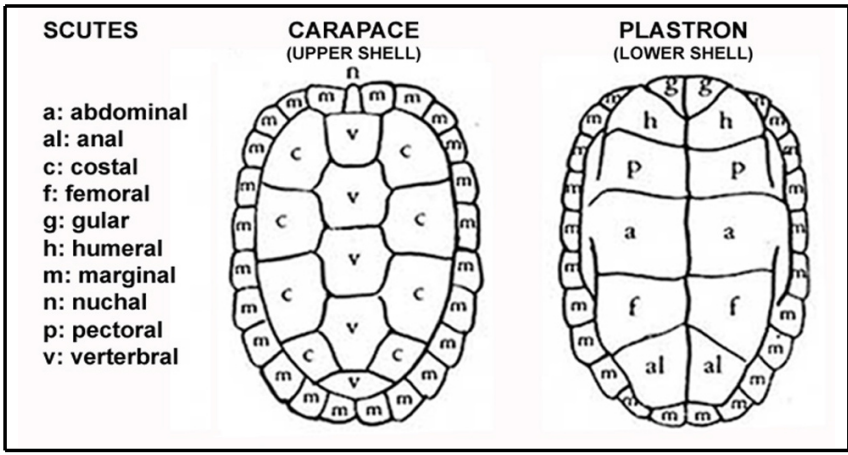

Figure 1. Turtle Anatomical Terminology Credits: Diagram taken from The Audubon Society Field Guide to North American Reptiles and Amphibians

\section{Snapping Turtles--family Chelydridae}

Snapping turtles have massive heads, powerful jaws, and long tails. These species spend most of their lives underwater, where they feed principally on other animals. When on land, snapping turtles are slow but can be dangerous and they will not hesitate to strike quickly to defend themselves. When harassed, snappers may release a strong and unpleasant odor from their musk glands, which is quite effective in discouraging predators.

Underwater, these freshwater species' greatest defense is camouflage. The dull olive or dark brown upper shell covered with mud and algae perfectly conceals them from predators. Instead of basking in the sun, snapping turtles like to rest in warm, shallow fresh water, sometimes burying themselves in the mud with only their eyes and nostrils exposed.

The alligator snapping turtle (Macroclemys temminckii) is the largest freshwater turtle in the world, weighing up to 150 pounds $(80 \mathrm{~kg})$. This fierce-looking giant has a triangular-shaped head, sharply hooked beak, long tail, and a serrated gray or brown carapace with three large keels, or ridges. In Florida, it is found only in the Panhandle and the northern peninsula, where it is recognized as a species of special concern, which gives this species an added awareness and protection by the state.
The alligator snapping turtle does not actively hunt but rests quietly on the bottom, mouth agape, luring fish into its yawning orifice with a unique worm-like structure that is actually part of its tongue. The alligator snapping turtle rarely ventures far from deep-water rivers or associated freshwater marshes or impoundments. Nesting females will wander a short distance from the water to lay their eggs in late April and May.

The smaller common snapping turtle (Chelydra serpentine) also occurs in Florida and averages 8-14 inches $(20-30 \mathrm{~cm})$ in length and 10 to 35 pounds (4.5-16 kg) in weight. Unlike its larger cousin, it is not restricted to rivers but typically inhabits ponds, lakes, and marshes. The carapace is usually a dull olive or dark brown, with little or no marking, and the plastron is a dull yellow. Its range includes the entire state of Florida. Once considered abundant, this species has declined with the loss (to agricultural and residential development) of our state's precious wetlands.

\section{Mud and Musk Turtles--family Kinosternidae}

This family includes the smallest turtles in Florida; all are denizens of freshwater habitats. Two genera are represented in Florida: Kinosternon, the mud turtles, and Sternotherus, the musk turtles. All species are small, ranging in size from 3 to 5 inches $(7.5-12 \mathrm{~cm})$. In profile, the upper shell is high and rounded and appears oval-shaped when viewed from above. What clearly distinguishes the two are their plastrons. A mud turtle has a two-hinged plastron that, when tightly closed against the upper shell, can completely encase the legs and body. A musk turtle is much more vulnerable, as the smaller plastron provides very little protection for the legs. All turtles in this family have two pairs of musk glands beneath the upper shell, and when annoyed they will discharge a strong, offensive odor. Although these small turtles may become a nuisance to fishermen because they will not hesitate to steal bait off a hook, they are otherwise harmless and should be carefully released.

The carapace of the mud turtles (Kinosternon baurii and Kinsternon subrubrum) is more broad and flat than that of the musk turtles. In the striped mud 
turtle ( $K$. baurii), three long, dull yellow stripes typically mark the brown or olive carapace, and there are two stripes on each side of the head; the eastern mud turtle (K. subrubrum) shell is not striped and it rarely has stripes on the head.

The head of the loggerhead musk turtle (Sternotherus minor) has dark spots or dots on a gray or olive background and becomes disproportionately enlarged in some older males. Stinkpot turtles (Sternotherus odoratus) have a moderately elongated, narrow, and unusually highly arched, dark brown carapace. Musk turtles may appear careless in their nesting habits, as they often lay their eggs on the surface of the ground, in fallen leaves, or buried in rotten wood.

\section{Gopher Tortoise--family Testudinidae}

Florida's only true tortoise, Gopherus polyphemus, or gopher tortoise, is a fine example of the slow moving, strictly terrestrial, herbivorous, well-muscled animal of lore. Habitats of the gopher tortoise include almost any well-drained, sandy, abundantly vegetated land. Gopher tortoises burrow deeply into the loose soil to escape predators and extreme hot and cold weather. Considered by some to be a nuisance in yards and pastures because of their burrowing habits, the gopher tortoise is very important in Florida's ecology. Many other animals including snakes, rabbits, skunks, frogs, and mice may share the burrows that support an entire biological community unto themselves. Because of this, as well as the continued loss of its habitat to the pressures of development and agriculture, gopher tortoises are designated as a species of special concern by the State of Florida.

\section{Box, Chicken, Map, and Spotted Turtles; Diamondback Terrapins; Cooters and Sliders--family Emydidae}

Compared to other emydids, box turtles are adapted to a more terrestrial habitat. Box turtles (Terrapene Carolina) derive their name from the structure of the plastron, which is divided by a central hinge allowing them to pull in the sides against the body and close up like a box when threatened. The carapace is brown, black, or yellowish brown, usually with many yellow or orange blotches. Several subspecies occur in Florida and are distinguished by color and size, with the largest ones occurring along the coast of the Panhandle.

Box turtles do not burrow, but spend hot, dry periods beneath logs in leaf litter or in puddles. They are common in some grassy, bushy areas but overall are a turtle of the forests, often occurring close to water where they may soak for days at a time. As omnivores, box turtles feed on leafy plants, berries and other fruits, as well as worms, slug, and insects.

Diamondback Terrapins (Malaclemys terrapin) were nearly hunted to extinction for their tasty meat, but have made somewhat of a comeback. As an estuarine species, terrapins have a special gland behind the corner of each eye to excrete excess salt from the body, and feed underwater on small crustaceans and mollusks. Terrapins are easily identified by their rough carapace. Concentric rings, rising step-like toward the center of each scute, give them the common name "diamondback". Terrapins spend most of their lives in shallow marine environments, although females must come ashore to lay their eggs in the sand. Their range includes all of coastal Florida, including the Keys.

The chicken turtle (Deirochelys reticularia) is characterized by an extremely long neck and a yellow and orange network pattern on the globe-shaped carapace. In Florida, this species inhabits freshwater lakes, ponds, drainage ditches, marshes, and sloughs. Their diet consists of worms, crayfish, and all kinds of insects.

Of the dozen or so species of map turtles, only two live in Florida. Both are similar in appearance with dark carapaces as well as limbs and heads patterned with light, yellowish strips and bars. They often can be seen basking on rocks and logs along West Florida rivers, or floating with just their heads above the surface and their shells hanging at an angle as they slowly tread water with their webbed hind feet. Graptemys barbouri, or Barbours map turtle, has extensive yellow markings on the head, and a high, slightly knobbed mid-dorsal ridge on the carapace. This species occurs only in the Apalachicola-Chiploa drainage system in Florida. Graptemys ernsti, or Ernst's map turtles, strongly 
resemble Barbours, except for subtle differences in color patterns. This species, which was only recently recognized by scientists as being distinct from its cousin, the Alabama map turtle, occurs in the Yellow and Escambia rivers in West Florida.

Commonly called "cooters" in Florida, the genus Pseudemys includes a variety of water turtles that are often referred to as basking turtles, as they seem to prefer this type of behavior much more so than any other group of turtles. They often can be seen piled on top of one another, and when disturbed the stack collapses and they topple into the water. Most have brown to black, highly-domed carapaces that for the casual observer are difficult to distinguish among species. All cooters are herbivorous, dining on aquatic leafy vegetation and algae.

The river cooter (Pseudemys concinna) has a brownish to black carapace with concentric yellow markings, and dark, doughnut-shaped marks around the edge of the carapace on the lower surface. May through July, the female digs one or more nests and lays up to 26 elliptically-shaped eggs about $13 / 8$ inches $(35 \mathrm{~mm})$ long. The river cooter is confined to spring runs, rivers, and lakes directly associated with rivers (e.g., impoundments). It requires abundant vegetation and sunlight.

The Florida cooter (Pseudemys floridana) is also called the coastal plain turtle, and inhabits lakes, marshes, and swamps where it feeds on aquatic vegetation. This species is identified by the high, almost humped dome of the carapace and relatively small head that is heavily striped with yellow.

The carapace of the Florida redbelly turtle (Pseudemys nelsoni) is blackish, highly arched, and bears a red bar on each costal scute. The plastron is yellow-orange to reddish and patternless in adults. Its range includes all of Florida where it can often be seen basking on logs and floating with other cooters on mats of vegetation.

Also in this family is the yellowbelly slider (Trachemys scripta), which can be identified by the conspicuous vertical yellow blotch behind the eye and a vertical yellowish bar on each scute on either side of the back. Millions of turtles of this species are raised each year as pets, but few of them actually survive to adulthood. The slider occurs naturally throughout the Panhandle and northern peninsula, but a related subspecies (the red-eared turtle) has been introduced in some parts of South Florida where it appears to be thriving. However, such unnatural releases are to be discouraged.

Probably the rarest turtle in Florida is the spotted turtle, Clemmys guttata. An inhabitant of wet, boggy areas, it has been recorded in North Florida less than two dozen times. A small species, achieving a shell length of 5-6 inches $(12.5-15 \mathrm{~cm})$, it is easily distinguished by a pattern of bright yellow spots on its otherwise black carapace.

\section{Softshell Turtles--family Trionychidae}

Softshell turtles are best known for their unusually soft, flexible, leather-like carapace. The neck is very long, with a narrow head and long, slender, snorkel-like proboscis. The jaws have folds of skin that look like lips covering the powerful, knife-sharp mandibles, which almost have the shearing power of a snapping turtle. The legs look more like flippers, and they have two claws on the end of each one. Like most aquatic turtles, softshell turtles enjoy basking and will rest on any object that extends above the surface of the water, pulling their limbs under the flabby carapace and stretching their long necks upward to the fullest extent.

There are three species of softshells in Florida. Both smooth and spiny softshells (Apalone mutica and $A$. spinifera) occur only in North Florida rivers, while the large Florida softshell (A. ferox) can occur in almost any fresh water body statewide. The carapace of the Florida softshell turtle is a uniform, dull brown, or brownish gray with large darker spots and faint light colored reticulation; this species can become quite large, with adult females occasionally measuring up to two feet $(60 \mathrm{~cm})$ long! Much of the diet of softshells consists of fish, most of which is probably found dead and scavenged.

\section{Marine Turtles--families Cheloniidae and Dermochelyidae}

Marine turtles are well adapted to life in the ocean. The front limbs are modified as flippers, and special glands located near the eyes excrete excess 
salt. All spend their entire lives at sea, except for a few crucial moments when the females emerge to dig their nests and lay their eggs in the sands of many Florida beaches.

Two families and five species of marine turtles inhabit Florida's coastal waters. The smallest (Kemps Ridley, Lepidochelys kempii) measures 24 inches $(61 \mathrm{~cm})$ and weighs about 80 pounds $(36 \mathrm{~kg})$. It is considered to be one of the rarest and most endangered turtles in the world. The leatherback (Dermochelys coriacea) is the largest of all living turtles, reaching six to eight feet in length and half a ton or more in weight. Most marine turtles are carnivorous, feeding on a variety of smaller and slow-moving sea life such as jellyfish, shrimp, and crab. The green turtle (Chelonia mydas), however, is an herbivore; it feeds almost exclusively on seagrasses. The hawksbill (Eretmochelys imbricate) even feeds on sponges among the coral reefs of the Florida Keys.

The Atlantic loggerhead (Caretta caretta) is probably the best known marine turtle in Florida, as it nests here extensively during the summer months. The elongated, oval carapace is reddish brown and is often mottled with olive. Protection efforts for the loggerhead have been fairly successful with the status being threatened rather than endangered like the other four species of marine turtles.

\section{Literature Cited}

Behler, J.L., and F.W. King. 1979. The Audubon Society Field Guide to North American Reptiles and Amphibians. Chanticleer Press, Inc., New York, NY.

Ernst, C.H. and R.W. Barbour. 1972. Turtles of the United States. University Press of Kentucky. Lexington, KY.

Carr, A. 1952. Handbook of Turtles. Cornell University Press. Ithaca, NY. 